\title{
PERANCANGAN SISTEM INFORMASI PENJUALAN SEPEDA MOTOR PADA PT. FORMULA DIPTAJATI JAKARTA
}

\author{
${ }^{1}$ Isma Santi Arini ${ }^{2}$ Susafa'ati \\ ${ }^{1}$ AMIK BSI Jakarta-Manajemen Informatika ${ }^{2}$ STMIK Nusa Mandiri-Teknik Informatika \\ Email : isma_santi@yahoo.co.id, susi_susafaati@yahoo.co.id
}

\begin{abstract}
Abstrak
PT. Formula Diptajati merupakan Perusahaan yang bergerak dibidang penjualan Sepeda Motor secara Cash maupun Credit. Proses penjualan masih dilakukan secara manual, yaitu pengolahan datanya masih konvensional. Dari permasalahan tersebut dibuat sebuah sistem penjualan motor. Metode yang digunakan pada penelitian ini menggunakan metode waterfall. Hasil dari penelitian ini adalah pembuatan sistem informasi penjualan sepeda motor yang memberikan kemudahan pada PT. Formula Diptajati dalam proses pengolahan data sepeda motor.
\end{abstract}

Kata Kunci: Penjualan Sepeda Motor, Sistem Informasi, Waterfall.

\begin{abstract}
PT. Formula Diptajati is a company engaged in the sale of Motorcycles in Cash or Credit. The sales process is still done manually, the data processing is still conventional. From the problem is made a motor sales system. The method used in this research using waterfall method. The result of this research is the making of motorcycle sales information system that gives convenience to PT. Formula Diptajati in motorcycle data processing.
\end{abstract}

Keywords: Information System, Motorcycle Sales, Waterfall. 


\section{PENDAHULUAN}

PT. Formula Diptajati merupakan Perusahaan yang bergerak dibidang penjualan Sepeda Motor secara Cash maupun Credit. Dengan proses penjualan yang masih manual dan belum terkomputerisasi, maka terjadi ketidak seimbangan antara produk dan sistem informasi penjualan.

Menurut Penelitian Fathoni dkk (2013) mengenai sistem informasi penjualan sepeda motor, penjualan sepeda motor masih menggunakan sistem konvensional yaitu pencatatan menggunakan buku besar sehingga penelitian bertujuan untuk mempermudah proses pencarian dan mengupdate suatu data dan memberikan kemudahan pada PT. Formula Diptajati dalam proses pengolahan data sepeda motor.

Hasil analisa dan pengamatan pada PT. Formula Diptajati maka penulis dapat mengemukakan beberapa permasalahan pokok yang khususnya terjadi pada sistem penjualan yang sedang berjalan, antara lain:

1. Proses pencatatan Surat Pesanan masih tulis tangan, dan hanya satu lembar yaitu warna putih sehingga dalam pengarsipan sering terjadi kesalahan dan dipakai dalam beberapa bagian dalam 1 arsip, dan terjadilah perselisihan.

2. Proses pembayarannya terlambat, karena kwitansi penjualan motor belum terkomputerisasi.

3. Pembuatan Laporan kurang cepat, karena dibutuhkan waktu untuk mengumpulkan arsip penjualan yang diperlukan serta sering terjadi kesalahan perhitungan karena kurangnya ketelitian.

4. Pencatatan dalam buku stok masih tulis tangan.

\section{TINJAUAN PUSTAKA}

\section{Model Waterfall (Air Terjun)}

Menurut Sommerville (2007:66), "model ini merupakan model yang paling pertama dipulikasikan. Model ini berasal dari proses sistem engineering yang lebih umum, karena proses dari tahap satu ke tahap selanjutnya mengalir kebawah, model ini dikenal sebagai waterfall model atau siklus hidup software".

Beberapa tahapan dalam waterfall model menurut Sommerville (2007:66).

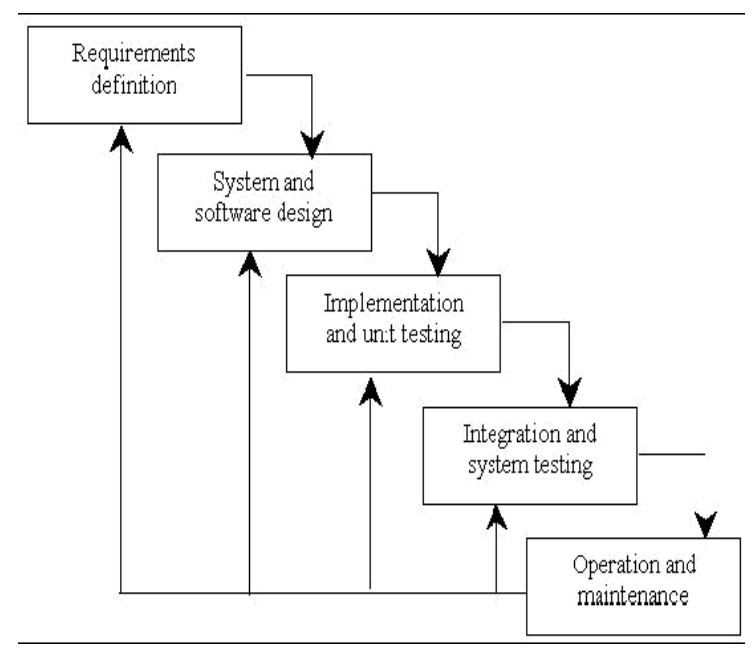

Sumber : Sommerville (2007:66)

\section{Gambar 1. Waterfall Model}

Tahap utama model ini dibagi kedalam 5 bagian berdasarkan pengembangan kegiatannya:

1. Analisis dan definisi kebutuhan :

Layanan, batasan, dan tujuan dari sistem ditetapkan melalui konsultasi dengan pengguna sistem. Semua itu didefinisikan secara detail dan bertindak sebagai spesifikasi sistem.

2. Disain sistem dan software:

Proses disain sistem membagi kebutuhan menjadi hardware atau software. Ini menetapkan hampir seluruh perancangan sistem. Disain software melibatkan pengidentifikasian dan penggambaran mengenai pemisahan dasar sistem software dan hubungannya.

3. Implementation and unit testing :

Dalam tahap ini, disain software adalah menyadari sebagai kumpulan program atau satuan program. Unit testing melibatkan verifikasi bahwa setiap unit telah mencapai spesifikasinya.

4. Integration and system testing :

Satuan program atau kumpulan program diintegrasikan dan di tes sebagai sistem yang telah selesai, untuk menjamin bahwa kebutuhan software telah terpenuhi. Setelah 
pengetesan, sistem software dikirimkan kepada pelanggan.

5. Operation and maintenance :

Biasanya, ini adalah bagian siklus hidup software yang paling lama. Sistem di-install dan dimasukkan kedalam penggunaan. Pemeliharaan melibatkan pembenaran kesalahan yang tidak ditemui dalam tahap awal siklus, meningkatkan implementasi satuan sistem, dan meningkatkan layanan sistem sehubungan ditemukannya kebutuhan baru.

Menurut Ian Sommerville (2007:67-68), "kelebihan dari waterfall model adalah dokumentasi dihasilkan dalam setiap tahap, dan ini cocok dengan model proses engineering". Masalah utama dari waterfall model ini adalah tidak fleksibelnya partisi dari proyek ke tahap yang berbeda. Komitmen harus dibuat dalam tahap awal dari proses ini, sehingga sulit menanggapi perubahan permintaan pelanggan. Oleh karena itu, waterfall model seharusnya hanya digunakan saat kebutuhan sangat dimengerti dan tidak mungkin berubah sama sekali dalam pengembangan sistem.

\section{METODE PENELITIAN}

Menunjang kelancaran penulisan ini, ada beberapa metode pengumpulan data yang digunakan. Adapun metode-metode pengumpulan data yang digunakan adalah :

\section{a. Metode Pengembangan Perangkat Lunak}

Menurut Sommerville (2007:66), "metode yang digunakan pada pengembangan perangkat lunak ini menggunakan model waterfall yang terbagi menjadi tiga tahapan, yaitu :

1. Analisis Kebutuhan

Pada Tahap Analisis Kebutuhan sangat menekankan pada masalah pengumpulan kebutuhan pengguna pada tingkatan sistem dengan menentukan konsep system beserta antarmuka atau interface yang menghubungkannya dengan lingkungan sekitar. Hasilnya berupa spesifikasi sistem untuk pengguna yaitu admin dan user.
2. Perancangan Sistem dan Perangkat Lunak Proses perancangan sistem menggunakan DFD dan perancangan database menggunakan ERD dan LRS.

3. Implementasi dan Pengujian Unit

Pada tahap ini, perancangan perangkat lunak direalisasikan sebagai serangkaian program atau unit program. Kemudian pengujian unit melibatkan verifikasi bahwa setiap unit program telah memenuhi spesifikasinya.

\section{b. Teknik Pengumpulan Data}

Penelitian yang dilakukan menggunakan teknik pengumpulan data, diantaranya :

1. Observasi

Penelitian Observasi dilakukan di PT. Formula Diptajati. Dalam penelitian ini, penulis mengadakan pengamatan dan menganalisis Sistem penjualan sehingga dapat diketahui hambatan-hambatan serta kekurangan - kekurangan yang terjadi dalam melaksanakan perancangan sistem penjualan tersebut dan data yang diperoleh lebih lengkap dan aktual.

2. Wawancara

Proses wawancara dilakukan Penulis secara langsung kepada Bapak Teguh selaku Pimpinan PT. Formula Diptajati guna mendapatkan informasi yang diberikan mengenai perusahaannya.

3. Studi Pustaka

Studi Pustaka menggunakan metode kepustakaan dengan mempelajari literature, buku-buku, majalah dan sumber-sumber lain yang berkaitan dengan penulisan, data yang ada serta mendapatkan gambaran mengenai materi yang digunakan.

\section{HASIL PENELITIAN DAN PEMBAHASAN}

\section{Prosedur Sistem Berjalan}

Hasil analisis Prosedur sistem berjalan yang diambil dari PT.Formula Diptajati Jakarta yaitu sistem penjualan sepeda motor. Prosedur Sistem yang dilakukan secara tunai dan kredit adalah sebagai berikut : 


\section{Prosedur Pemesanan Barang}

Customer datang langsung ke dealer Formula Motor dengan membawa KK, KTP, kemudian customer memesan barang ke bagian penjualan atau sales counter. Bagian penjualan mengecek barang ke buku stok, jika barang yang dipesan ada, maka bagian penjualan membuatkan surat pesanan/PO yang hanya satu lembar saja yaitu warna putih yang nantinya untuk di arsipkan.

\section{Prosedur Pembayaran Tunai Jika} Penjualan Tunai

Setelah customer melakukan pemesanan barang, customer langsung dapat melakukan pembayaran lunas kepada kasir dan dibuatkan kwitansi rangkap tiga, warna putih untuk customer dan kwitansi merah untuk di arsipkan, lalu kwitansi warna kuning diserahkan Kepala Operasional lalu ditanda tangani.

\section{Prosedur Pengajuan Perjanjian Kredit} Jika Penjualan Kredit

Bagian sales counter mengisi formulir permohonan pembiayaan individu dari data KK, KTP dan SP merah customer, lalu mengajukan proses kredit melalui admin sales ke Federal International Finance (FIF) atau Leasing lainnya yang telah bekerja sama. Kemudian Pihak Leasing memberikan kabar approve dengan mengeluarkan Purchase Order (PO) di berikan kebagian Admin Sales.

\section{Prosedur Pembayaran Uang Muka Jika} Penjualan Kredit

Setelah PO di keluarkan, customer bisa langsung membayar uang muka ke bagian Kasir dan PO di arsip. Bagian penjualan membuatkan kwitansi rangkap tiga, kwitansi warna putih di berikan ke customer dan kwitansi merah untuk di arsipkan, lalu kwitansi warna kuning diserahkan Kepala Operasional lalu ditanda tanganinya.

\section{Prosedur Pengiriman Barang}

Admin sales membuat surat jalan 3 rangkap. Berdasarkan Surat Jalan yang di terima oleh bagian gudang, maka bagian gudang menyiapkan barang pesanan. Lalu surat jalan dan barang pesanan di cek berdasarkan data kwitansi. Setelah sesuai maka barang pesanan dikirim oleh supir dan kenek ke tempat customer (jika minta diantar) dan surat jalan diberikan ke customer, setelah di tandatangani oleh customer, surat jalan warna kuning untuk customer yang nantinya harus dibawa pada saat pengambilan STNK dan surat jalan warna putih untuk di arsipkan dan merah untuk bagian gudang.

\section{Proses pembuatan Laporan}

Bagian Admin Sales membuat laporan penjualan berdasarkan data surat jalan putih dan data kwitansi merah, setelah data lengkap maka bagian penjualan membuat laporan penjualan bulanan untuk di serahkan kepada bagian Administrasi dan di cek oleh PIC Administrasi dan diserahkan kepada Pimpinan.

\section{Diagram Alir Data (DAD) Sistem Berjalan}

Perancangan sistem berjalan digambarkan dengan menggunakan Diagram Alir Data (DAD) yang terdiri dari diagram konteks, diagram nol, dan diagram detail.

\section{Diagram Kontek Sistem Berjalan}

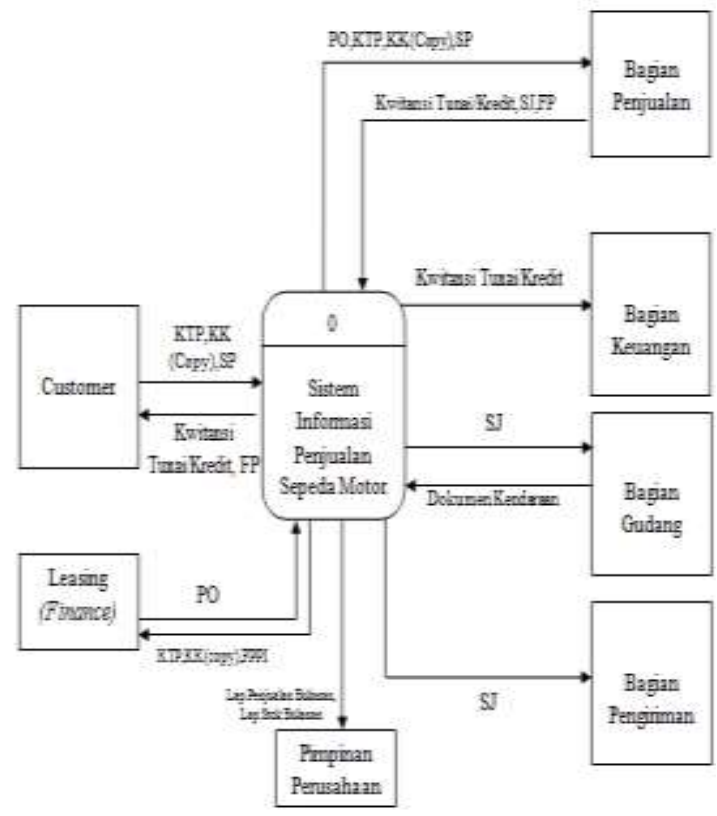

Gambar 2. Diagram Kontek Sistem Berjalan Sumber : Hasil Penelitian (2017) 
Diagram Nol Sistem Berjalan

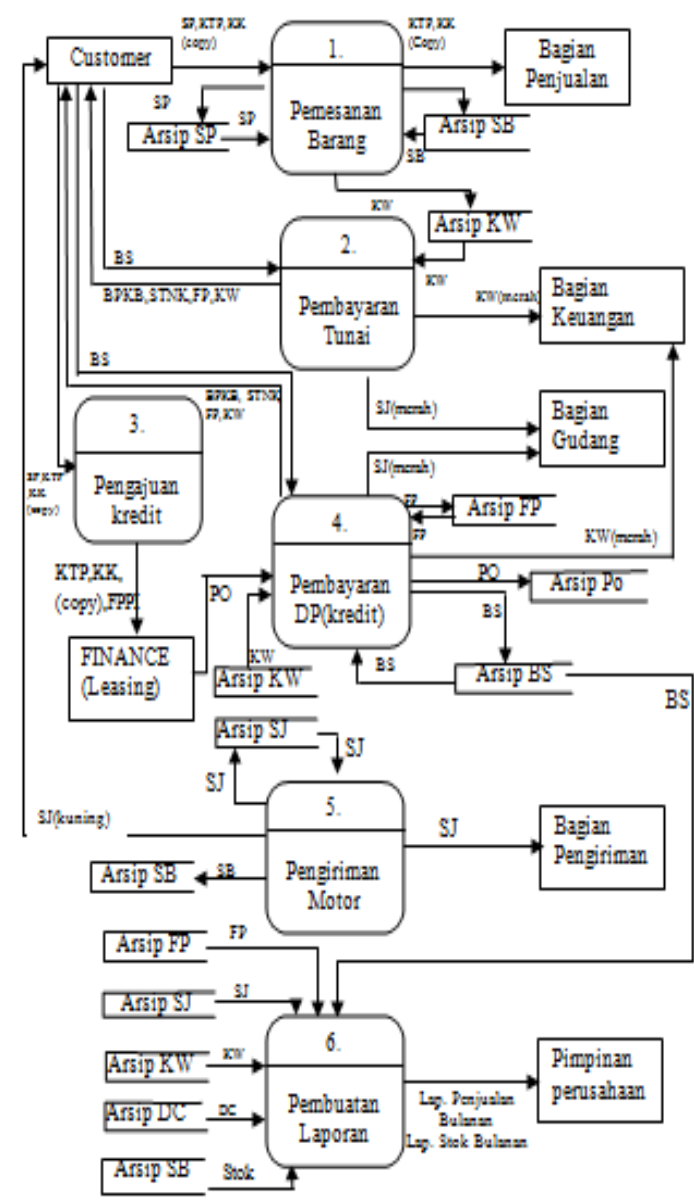

Gambar 3. Diagram Nol Sistem Berjalan Sumber : Hasil Penelitian (2017)

\section{Diagram Detail 1.0 Sistem Berjalan}

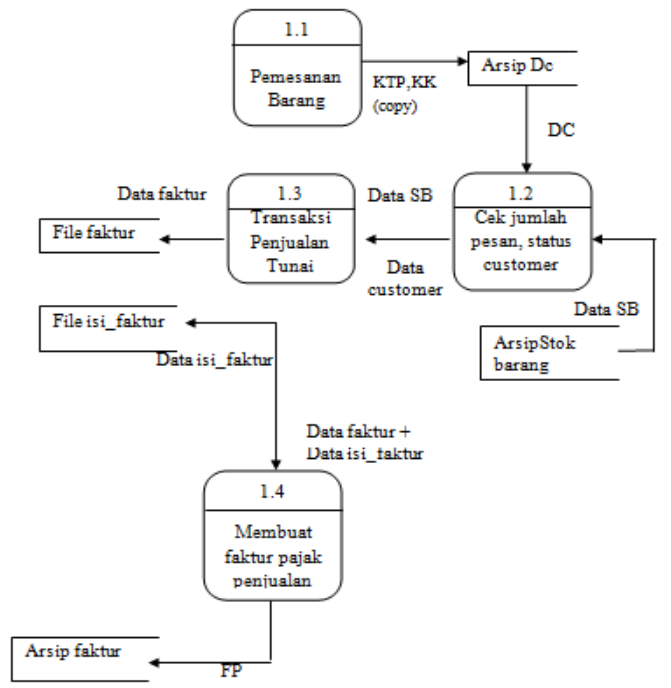

Gambar 4. Diagram Detail 1.0 Sistem Berjalan Sumber : Hasil Penelitian (2017)

\section{Diagram Detail 2.0 Sistem Berjalan}

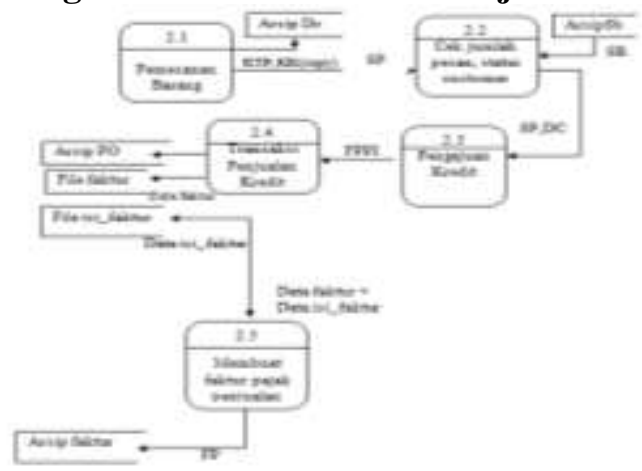

Gambar 5. Diagram Detail 2.0 Sistem Berjalan

Sumber : Hasil Penelitian (2017)

\section{Diagram Detail 3.0 Sistem Berjalan}

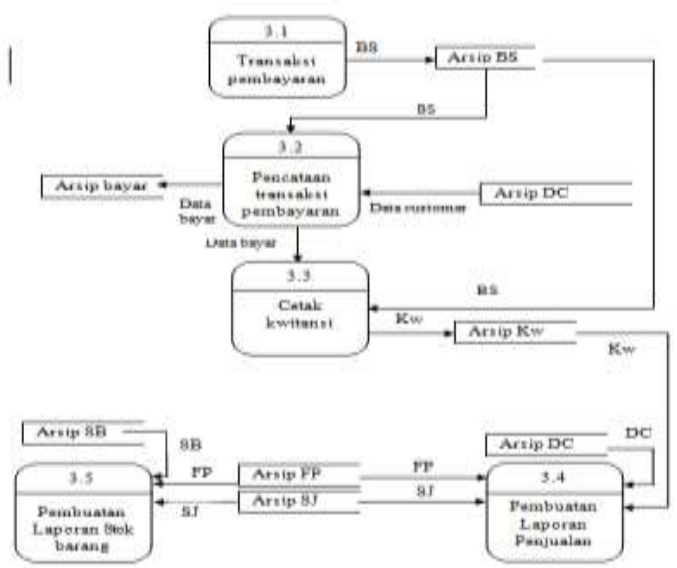

Gambar 6. Diagram Detail 3.0 Sistem Berjalan

Sumber : Hasil Penelitian (2017)

\section{Prosedur Sistem Usulan}

Sistem usulan yang penulis ajukan mungkin tidak terlalu berbeda jauh dengan yang berjalan. Prosedur sistem yang penulis usulkan terdiri dari beberapa proses antara lain sebagai berikut :

\section{Prosedur Pemesanan Barang}

Customer datang langsung ke dealer PT.Formula Diptajati dengan membawa KK, KTP dan memesan barang ke bagian penjualan. Bagian penjualan mengecek barang berdasarkan file stok, jika barang yang di pesan ada maka bagian penjualan menginput file customer dan menginput file pesanan dua rangkap. Warna kuning untuk 
customer, putih untuk gudang dan KK,KTP di arsip.

\section{Prosedur Pembayaran Tunai Jika} Penjualan Tunai

Setelah customer melakukan pemesanan barang, customer langsung dapat melakukan pembayaran lunas kepada kasir dan menginput file kwitansi rangkap 3, warna putih untuk customer dan kwitansi merah untuk di arsipkan, lalu kwitansi warna kuning diserahkan Kepala Operasional dan ditanda tanganinya.

\section{Prosedur Pengajuan Perjanjian Kredit Jika Penjualan Kredit}

Bagian penjualan mencetak formulir permohonan pembiayaan individu berdasarkan file pesanan lalu mengajukan proses kredit ke Leasing atauFederalInternational Finance (FIF). Kemudian FIF memberikan kabar approvedengan mengeluarkan Purchase Order (PO) di berikan ke bagian penjualan.

\section{Prosedur Pembayaran Uang Muka Jika} Penjualan Kredit

Setelah PO di keluarkan, customer bisa langsung membayar uang muka ke bagian penjualan. Kemudian bagian penjualan menginput kwitansi berdasarkan file pembayaran. Kwitansi warna putih untuk customer dan merah untuk diarsip. Bagian penjualan juga menginput file $\mathrm{PO}$ dan di arsip.

\section{Prosedur pengiriman Barang}

Admin sales membuat surat jalan 3 rangkap berdasarkan file customer dan kwitansi. Surat Jalan diberikan ke bagian gudang, maka bagian gudang menyiapkan barang pesanan. Lalu surat jalan dan barang pesanan di cek berdasarkan data kwitansi. Setelah sesuai maka barang pesanan dikirim oleh supir dan kenek ke tempat customer (jika minta diantar) dan surat jalan diberikan ke customer , setelah di tandatangani oleh customer, surat jalan warna kuning untuk customer yang nantinya harus dibawa pada saat pengambilan STNK dan surat jalan warna putih untuk di arsipkan dan merah untuk bagian gudang.

\section{Prosedur Pembuatan Laporan}

Bagian Admin Sales membuat laporan penjualan berdasarkan data penjualan pada file stok barang, file customer, file surat jalan dan file kwitansi, setelah data lengkap maka bagian penjualan menyerahkan laporan penjualan bulanan untuk di serahkan kepada bagian Administrasi dan di cek oleh PIC Administrasi lalu diserahkan kepada Pimpinan.

\section{Diagram Alir Data (DAD) Sistem Usulan}

Perancangan sistem usulan digambarkan dengan menggunakan Diagram Alir Data (DAD) yang terdiri dari diagram konteks, diagram nol, dan diagram detail usulan.

\section{Diagram Konteks Sistem Usulan}

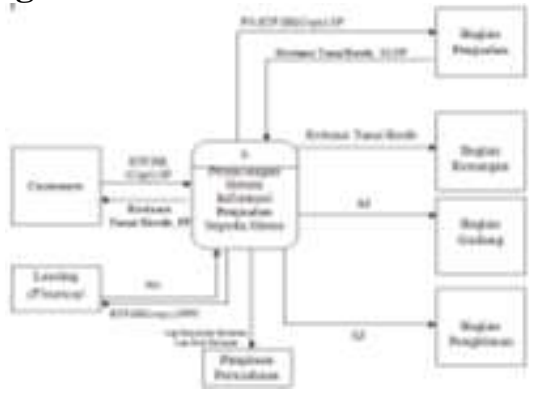

Gambar 7. Diagram Konteks Sistem Usulan

Sumber : Hasil Penelitian (2017)

\section{Diagram Nol Sistem Usulan}

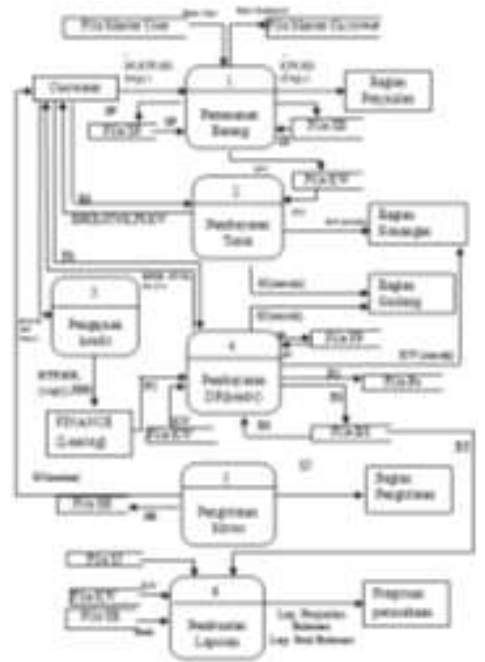

Gambar 8. Diagram Nol Sistem Usulan 


\section{Diagram Detail 1.0 Sistem Usulan}

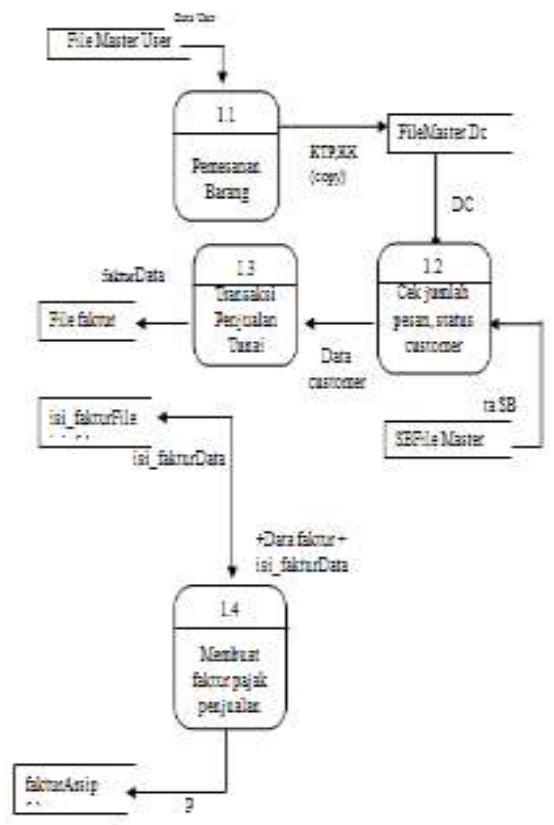

Gambar 9. Diagram Detail 1.0 Sistem Usulan Sumber : Hasil Penelitian (2017)

\section{Diagram Detail 2.0 Sistem Usulan}

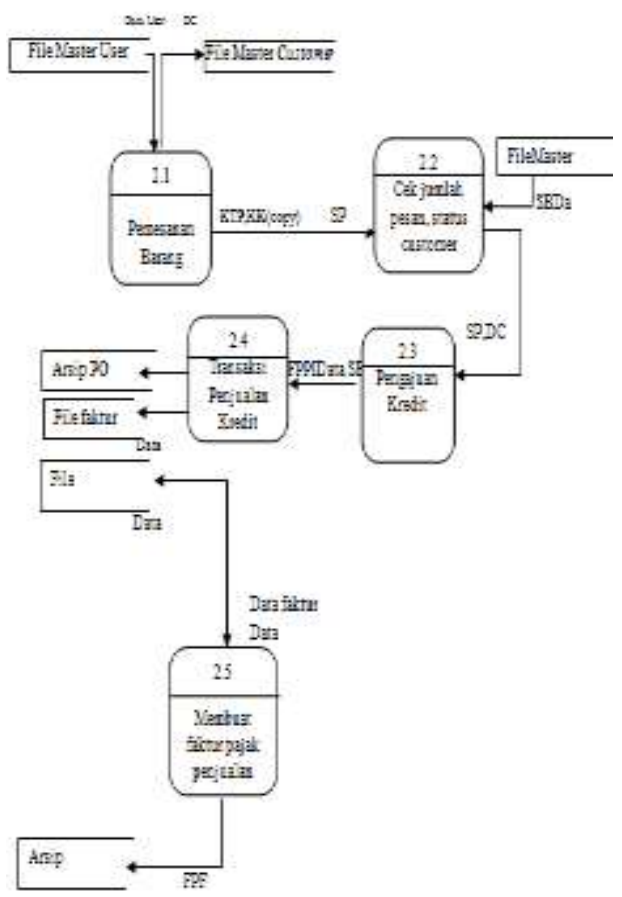

Gambar 10. Diagram Detail 2.0 Sistem Usulan Sumber : Hasil Penelitian (2017)

\section{Diagram Detail 3.0 Sistem Usulan}

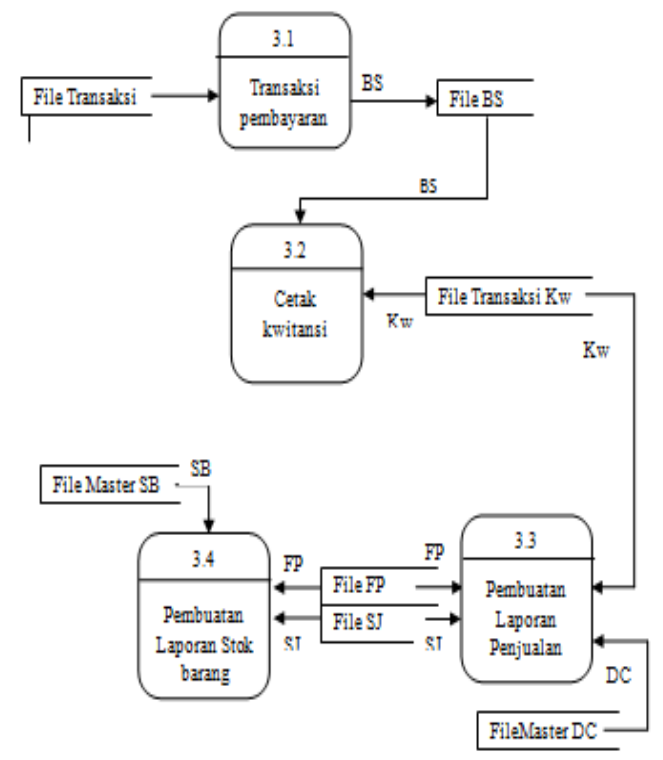

Gambar 11. Diagram Detail 3.0 Sistem Usulan

Sumber : Hasil Penelitian (2017)

\section{Entity Relationship Diagram}

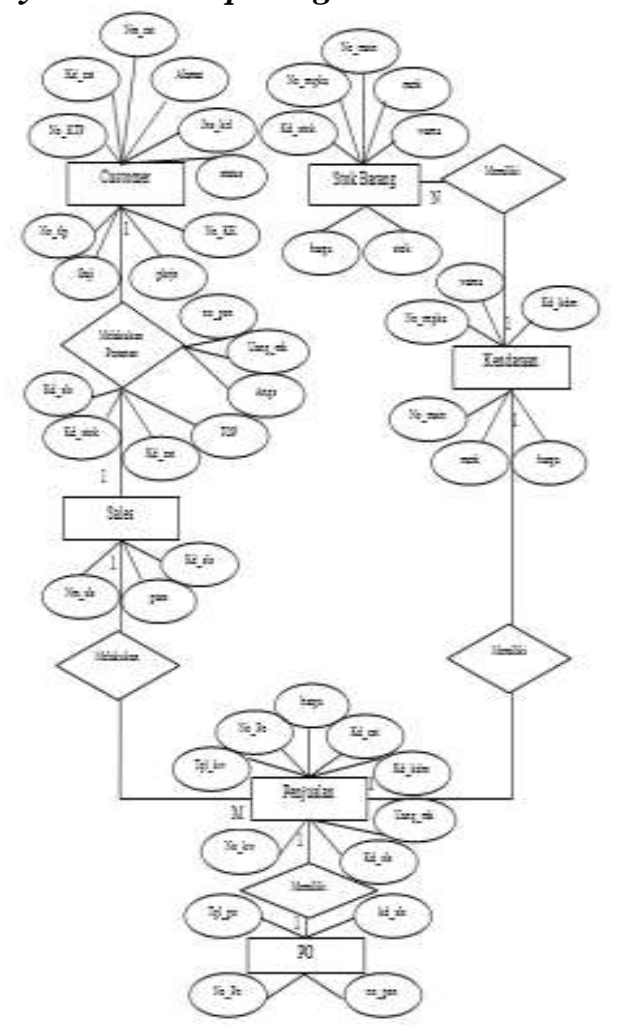

Gambar 12. Entity Relationship Diagram 
Logical Record Structure

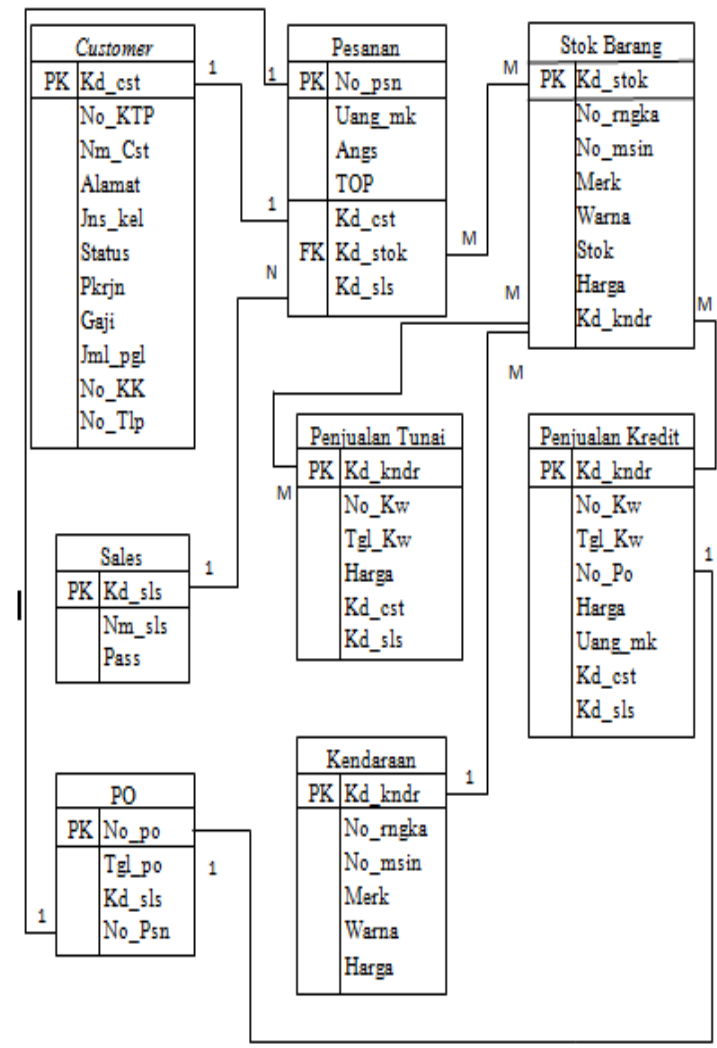

Gambar 13. Logical Record Structure

\section{Jadwal Implementasi}

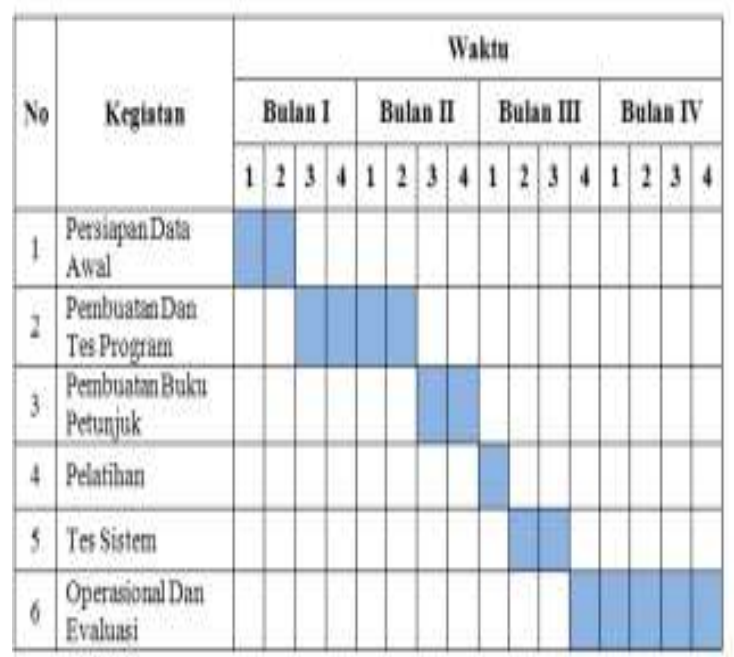

Gambar 14. Jadwal Implementasi

Sumber : Hasil Penelitian (2017)

\section{KESIMPULAN DAN SARAN}

Kesimpulan dari penelitian ini menghasilkan rancangan sistem yaitu dimulai dari prosedur sistem usulan dengan mendesain Diagram Alur Data sistem usulan dan Entity Relationship Diagram yang dapat memudahkan pekerjaan serta proses penjualan pada PT.Formula Diptajati.

Hasil penelitian ini menyusun prosedurprosedur dimulai dari prosedur pemesanan barang, pembayaran baik tunai maupun kredit, dan pengiriman barang sampai kepada pembuatan laporan penjualan sepeda motor khususnya yang penulis rancang ini berpedoman pada laporan penjualan dan stok barang yang ada pada PT.Formula Diptajati saat ini sehingga masalah cepat teratasi, dan informasi dapat diakses kapan pun.

Adapun saran-saran yang disampaikan berdasarkan hasil pengamatan dan analisa selama melakukan pengumpulan data di PT. Formula Diptajati adalah sebagai berikut :

1. Sebelum menerapkan sistem ini perlu dilakukan uji coba dan selama masa uji coba sistem yang lama tetap dipakai.

2. Jika uji coba menunjukan hasil yang positif maka perlu pelatihan bagi karyawan yang akan terlibat dalam pemakaian sistem ini.

3. Sistem komputerisasi perlu diterapkan pada PT. Formula Diptajati walaupun pada saat ini sistem belum efektif untuk dapat diterapkan secara meyeluruh karena akan dapat merubah keadaan dari sistem yang ada.

\section{DAFTAR PUSTAKA}

Agus Mulyanto, 2009, Sistem Informasi Konsep dan Aplikasi: Pustaka Pelajar, Yogyakarta.

Fathoni, Purnama, Wardati, 2013, Pembangunan Sistem Informasi Penjualan Sepeda Motor Bekas Pada Unit Dagang (Ud) Merdeka Motor Pacitan, IJNS, 23025700:2.

Kadir, Abdul, 2009, Pengenalan Sistem Informasi, Andi Offset, Yogyakarta.

Sommerville, Ian, 2007, Software Engineering:

Rekayasa Perangkat Lunak Edisi 8, Erlangga, Jakarta. 